University of Nebraska - Lincoln

DigitalCommons@University of Nebraska - Lincoln

\title{
Effects of distance from cattle water developments on grassland birds
}

\author{
Andrea L. Fontaine \\ Oregon State University \\ Patricia L. Kennedy \\ Oregon State University, pat.kennedy@oregonstate.edu \\ Douglas $\mathrm{H}$. Johnson \\ USGS Northern Prairie Wildlife Research Center, Douglas_H_Johnson@usgs.gov
}

Follow this and additional works at: https://digitalcommons.unl.edu/usgsnpwrc

Part of the Other International and Area Studies Commons

Fontaine, Andrea L.; Kennedy, Patricia L.; and Johnson, Douglas H., "Effects of distance from cattle water developments on grassland birds" (2004). USGS Northern Prairie Wildlife Research Center. 206.

https://digitalcommons.unl.edu/usgsnpwrc/206

This Article is brought to you for free and open access by the US Geological Survey at DigitalCommons@University of Nebraska - Lincoln. It has been accepted for inclusion in USGS Northern Prairie Wildlife Research Center by an authorized administrator of DigitalCommons@University of Nebraska - Lincoln. 


\title{
Effects of distance from cattle water developments on grassland birds
}

\author{
ANDREA L. FONTAINE, PATRICIA L. KENNEDY, AND DOUGLAS H. JOHNSON
}

\begin{abstract}
Authors are Graduate Research Assistant and Associate Professor, Department of Fisheries and Wildlife and Eastern Oregon Agricultural Research Center, Oregon State University, Corvallis, Ore. 97330; and Supervisory Statistician, U.S. Geological Survey, Northern Prairie Wildlife Research Center, Jamestown, N.D. 58401. At the time of the research, the senior and second authors were Graduate Research Assistant and Associate Professor, Graduate Degree Program in Ecology and Department of Fishery and Wildlife Biology, Colorado State University, Fort Collins, Colo. 80523.
\end{abstract}

Abstract

Many North American grassland bird populations appear to be declining, which may be due to changes in grazing regimes on their breeding areas. Establishment of water developments and confining cattle (Bos taurus L.) to small pastures often minimizes spatial heterogeneity of cattle forage consumption, which may lead to uniformity in vegetative structure. This increased uniformity may provide suitable habitat for some bird species but not others. We assessed how cattle use, vegetative structure, and bird population densities varied with increasing distance from water developments (0-800 m) on the Little Missouri National Grassland (LMNG) in North Dakota. Lark buntings (Calamospiza melancorys Stejneger), which are typically associated with low vegetative cover, decreased with increasing distance from water developments. Horned larks (Eremophila alpestris L.), also a low-cover associate, followed a similar but weaker trend. Densities of another low-cover associate as well as moderate- and high-cover associates were not related to distance from water. Vegetative height-density and litter depth increased by 50 and $112 \%$, respectively, while cowpie cover and structural variability decreased by 51 and $24 \%$, respectively, with distance from water. Confidence interval overlap was common among all measures, showing substantial variability among study sites. Our results indicate cattle use is higher closer to water developments, and this pattern may positively affect the densities of lark buntings and horned larks. The absence of density gradients in the other bird species may be due to the paucity of locations > $800 \mathrm{~m}$ from water on the LMNG.

Key Words: distance sampling, livestock grazing, mixed-grass prairie, North Dakota, wildlife

Financial support for this research was provided by U.S. Geological Survey's Northern Prairie Wildlife Research Center, U.S. Forest Service Region 1 office, Colorado State University's College of Natural Resources, the Colorado Division of Wildlife Diversity Scholarship Program, and the J.E. Weaver Small Grants Program of The Nature Conservancy's Nebraska Chapter. We thank the U.S. Forest Service, Northern Prairie Wildlife Research Center, and the Colorado Cooperative Fish and Wildlife Research Unit for logistical support. Meghan F. Dinkins and Kathy D. Ruffert provided invaluable field assistance. Kenneth P. Burnham and Aaron R. Ellingson of Colorado State University provided assistance with program DISTANCE. N. Thompson Hobbs and James K. Detling provided helpful advice throughout this project. J. Brummer and two anonymous reviewers provided insightful comments on an earlier draft of this manuscript. Publication costs were supported by the Thomas G. Scott Publication Fund of the Department of Fisheries and Wildlife, Oregon State University.

Manuscript accepted 16 Aug. 03.

\section{Resumen}

Muchas de las poblaciones de aves de los pastizales de Norteamérica parecen estar disminuyendo, lo cual puede ser debido a cambios de los regímenes de apacentamiento en sus áreas de apareamiento. El establecimiento de aguajes y el confinamiento del ganado bovino (Bos taurus L.) en potreros pequeños a menudo minimiza la heterogeneidad espacial del consumo de forraje por el ganado, lo que puede conducir a una uniformidad en la estructura de la vegetación. Este incremento en la uniformidad puede proveer un hábitat apropiado para algunas especies de aves, pero no para otras. En los Pastizales Nacionales Little Missouri (LMNG), situados en North Dakota, evaluamos como el uso del ganado, la estructura de la vegetación y las densidades de poblaciones de aves variaron al incrementar la distancia a partir de los aguajes $(0-800 \mathrm{~m})$. Los "Lark buntings" (Calamospiza melancorys Stejneger), los cuales típicamente están asociadas con una cobertura vegetativa baja, disminuyeron al incrementar la distancia desde los aguajes. La especie "Horned larks" (Eremophila alpestris L.), la cual también esta asociada a una cobertura vegetativa baja, siguió una tendencia similar pero mas débil. Las densidades de otra especies asociadas a cobertura baja, así como de otras especies asociadas con coberturas altas y moderadas, no estuvieron relacionadas con la distancia a partir de los aguajes. La densidad y altura vegetativa y profundidad del mantillo se incrementaron en 50 y $112 \%$ respectivamente, mientras la cobertura de deposiciones fecales y la variabilidad estructural disminuyeron en 51 y $24 \%$ respectivamente con la distancia del aguaje. El traslape de los intervalos de confianza fue común entre todas las mediciones, mostrando una variabilidad substancial entre los sitios de estudio. Nuestros resultados indican que el uso del ganado es muy alto cerca de los aguajes y este patrón puede afectar positivamente las densidades de "Lark buntings"y "Horned larks". La ausencia de gradientes de densidad en las otras especies de aves puede deberse a la escases de localidades mayores de $800 \mathrm{~m}$ a partir de los aguajes en el LMNG.

North American grassland bird populations have declined dramatically in recent years (Igl and Johnson 1997, Peterjohn and Sauer 1999). Most of the bird species that breed on North American grasslands also winter on this continent; therefore, population declines of these species are likely associated with changes in North American processes (Knopf 1994), such as habitat loss or modification. 
On avian breeding grounds in the Great Plains, the landscape has been significantly modified since European settlement (Samson and Knopf 1994). Native ungulates, primarily bison (Bos bison L.), were replaced with domestic livestock, primarily cattle (Bos taurus L.) (Knopf 1994). Cattle movements were confined by fences, unlike their predecessors (Knopf 1994, Hartnett et al. 1997). This grazing regime transformation may have led to a homogenization of grazing (Knopf 1996), resulting in relatively uniform vegetative structure (Hartnett et al. 1997). Modern cattle-grazing operations often aim to minimize spatial heterogeneity of forage consumption and to maximize carrying capacity within pastures (Walker 1995). This heterogeneity is often minimized by making water more accessible to cattle (Hart et al. 1993) in the form of increased numbers of water developments. However, even with these changes, spatial heterogeneity in vegetative structure as a function of distance from water developments has been observed (Roath and Krueger 1982, Irving et al. 1995).

Assessing the degree of homogeneity in vegetative structure and bird population densities as a function of distance from water developments may yield insights into how rangeland management practices affect breeding birds and their habitats. Our objectives were to assess how cattle use, vegetative structure, and bird population densities varied with increasing distance from livestock water developments in mixed-grass prairie in southwestern North Dakota. This was an appropriate study location because a large proportion of this area is managed for grazing and has numerous water developments.

\section{Material and Methods}

\section{Study Region}

We conducted this study in areas of mixed-grass prairie in southwestern North Dakota, USA. The landscape is characterized by gullied ravines and valleys interspersed with prairie uplands (Hansen et al. 1984). At the nearby Medora weather station, mean temperature and precipitation from 1971-2000 were $6.8^{\circ} \mathrm{C}$ and 378 $\mathrm{mm}$, respectively (National Climatic Data Center 2000). A mixture of medium-tall bunchgrasses and short grasses dominates the native vegetation in the uplands, including needle-and-thread grass
[Hesperostipa comata (Trin. \& Rupr.) Barkworth] and western wheatgrass (Pascopyrum smithii P.A. Love) (Weaver and Albertson 1956). Shrubs such as western snowberry (Symphoricarpos occidentalis Hook.) and introduced grasses such as crested wheatgrass [Agropyron cristatum (L.) Gaertn.] are also common in this region.

\section{Site Selection}

We conducted our study from May to July 1999 and 2000 in pastures on the Little Missouri National Grassland (LMNG) $\left(46^{\circ} 37^{\prime}\right.$ to $47^{\circ} 48^{\prime} \mathrm{N}, 103^{\circ} 04^{\prime}$ to $\left.103^{\circ}-46^{\prime} \mathrm{W}\right)$. The LMNG encompasses 415,343 ha in southwestern North Dakota (Fig. 1) and is managed by the U.S. Forest Service (USDA-USFS 2001). We established study sites in 20 and 40 pastures in 1999 and 2000, respectively. Cattle water developments exist throughout these pastures. Current stocking rates were not available for most of our study sites, although records from the early 1990's were available for 12 of them. Stocking rates varied between 0.74 and 1.76 animal unit months (AUM) ha ${ }^{-1}$, with an average of 1.13 (U.S. Forest Service Dakota Prairie Grasslands, unpublished data).

To evaluate gradients of grazing intensity, we established study sites where we could locate 3-5 sampling points along a transect that originated from a water development. We established sampling points every $200 \mathrm{~m}$ along each transect, up to a maximal distance of 600 or $800 \mathrm{~m}$ from the development (or any other water

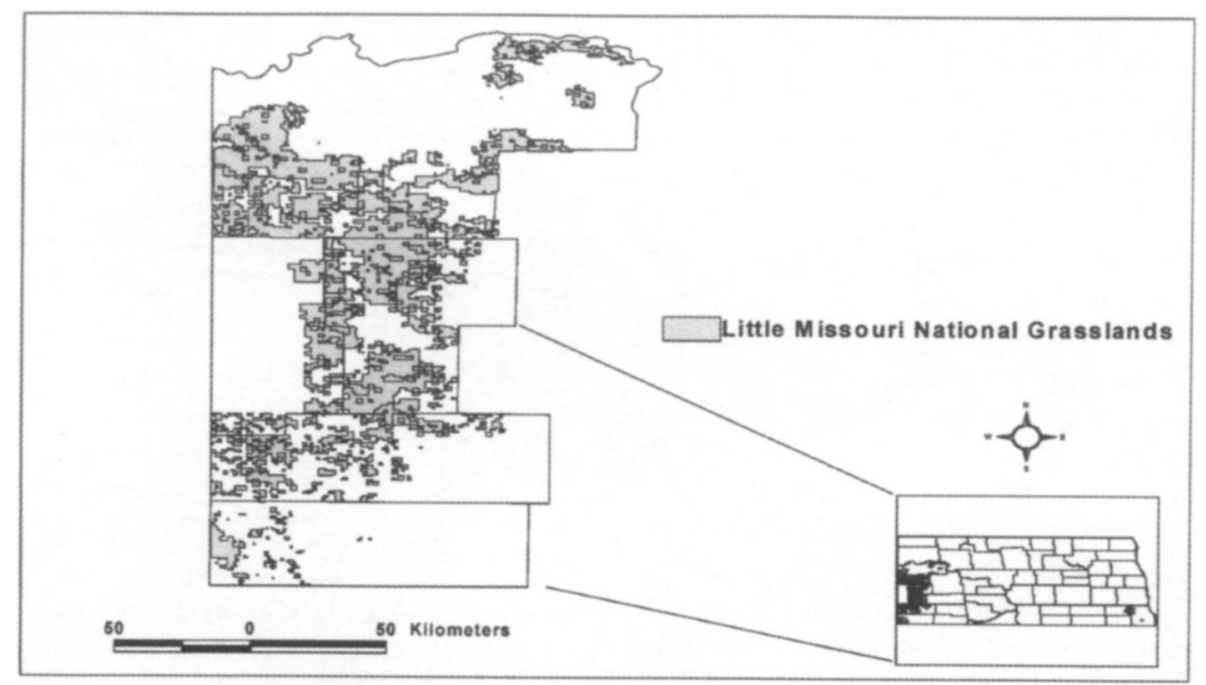

Fig. 1. The Little Missouri National Grassland in North Dakota, where bird and vegetative sampling points were located in 1999 and 2000. sources). Distances $>800 \mathrm{~m}$ from water developments could not be located in the study area. In 2000 , we also established points adjacent to the water development. Each sampling point was the center of a $100-\mathrm{m}$ radius area. We collected data at 64 and 168 points in 1999 and 2000, respectively.

\section{Bird Surveys}

Observers conducted 2 bird surveys at each sampling point per year. The sampling periods were 1-29 June and 23 June -10 July in 1999, and 20 May-12 June and 17 Jun-5 July in 2000 . We conducted each 5-minute survey between sunrise and 3.5 hours afterwards, when there was no fog or precipitation, and when average wind speeds were $<3.5 \mathrm{~m} \mathrm{sec}^{-1}$. We commenced each survey upon arrival at the point, or on approach to it if we flushed a bird from the sampling area. During surveys, we recorded all visually or aurally detected adult birds within $100 \mathrm{~m}$, noting its species and gender. Birds that did not appear to have territories in the sampling area and were flying over it were not included in data analyses. We employed distance sampling methodology (Buckland et al. 1993) to estimate bird densities.

\section{Vegetative Surveys}

We conducted vegetative surveys at each point once during 5-29 June in 1999 and twice during 17 May-4 July in 2000. We conducted 2 surveys in 2000 to characterize within-season variation in vegeta- 
tive structure. Each survey consisted of 35 sampling plots within the sampling area. Most plots were 5-m radius circles. We located 1 plot at the sampling point and 4 plots $50 \mathrm{~m}$ from the point, each located at a different $90^{\circ}$ bearing from the transect. For the $0-\mathrm{m}$ points, the sampling area was a half-circle, and we established one halfcircle plot at the point and 2 full-circle plots $50 \mathrm{~m}$ from the point and $90^{\circ}$ apart. At each plot, observers measured vegetative height-density and litter depth $5 \mathrm{~m}$ from the plot center in each cardinal direction, and visually estimated percent cover of cattle droppings ("cowpie cover") within the plot. We measured height-density using a Robel pole ("Robel measure") (Robel et al. 1970).

\section{Data Analysis}

\section{Bird Density Estimation}

We estimated bird densities with the program DISTANCE 3.5 (Thomas et al. 1998), which estimates species' densities by accounting for the detection probability of each species. Using DISTANCE, we determined that detection probabilities did not substantially differ across years, and thus, pooled data across years for further estimation. We estimated detection probabilities and densities by year for the most common species observed at the study sites: Baird's sparrows (Ammodramus bairdii Audubon), chestnut-collared longspurs (Calcarius ornatus Townsend), grasshopper sparrows (Ammodramus savannarum Gmelin), and western meadowlarks (Sturnella neglecta Audubon) for both years, and for lark buntings, horned larks, and Savannah sparrows (Passerculus sandwichensis Gmelin) in 2000. For more information on the density estimation procedure, see Lueders (2002).

\section{Data Summarization and Analysis}

For each point each year, we calculated means for vegetative variables based on all sampling plot values (PROC MEANS, SAS Institute 1990). For the 2000 data, we generated grand means across periods. We calculated final means and $95 \%$ confidence intervals across years for all vegetative variables by distance category and we did the same for bird densities. We generated coefficients of variation of the Robel measure ("CVRobel") to evaluate withinpoint heterogeneity in vegetative structure. We pooled vegetative data across periods and years because confidence intervals for periods and years overlapped in most cases. We plotted means and confidence intervals as a function of distance from water to examine the patterns. We also evaluated effects of distance from water on bird densities, vegetation, and cattle use using linear regression on the means (PROC REG, SAS Institute 1990).
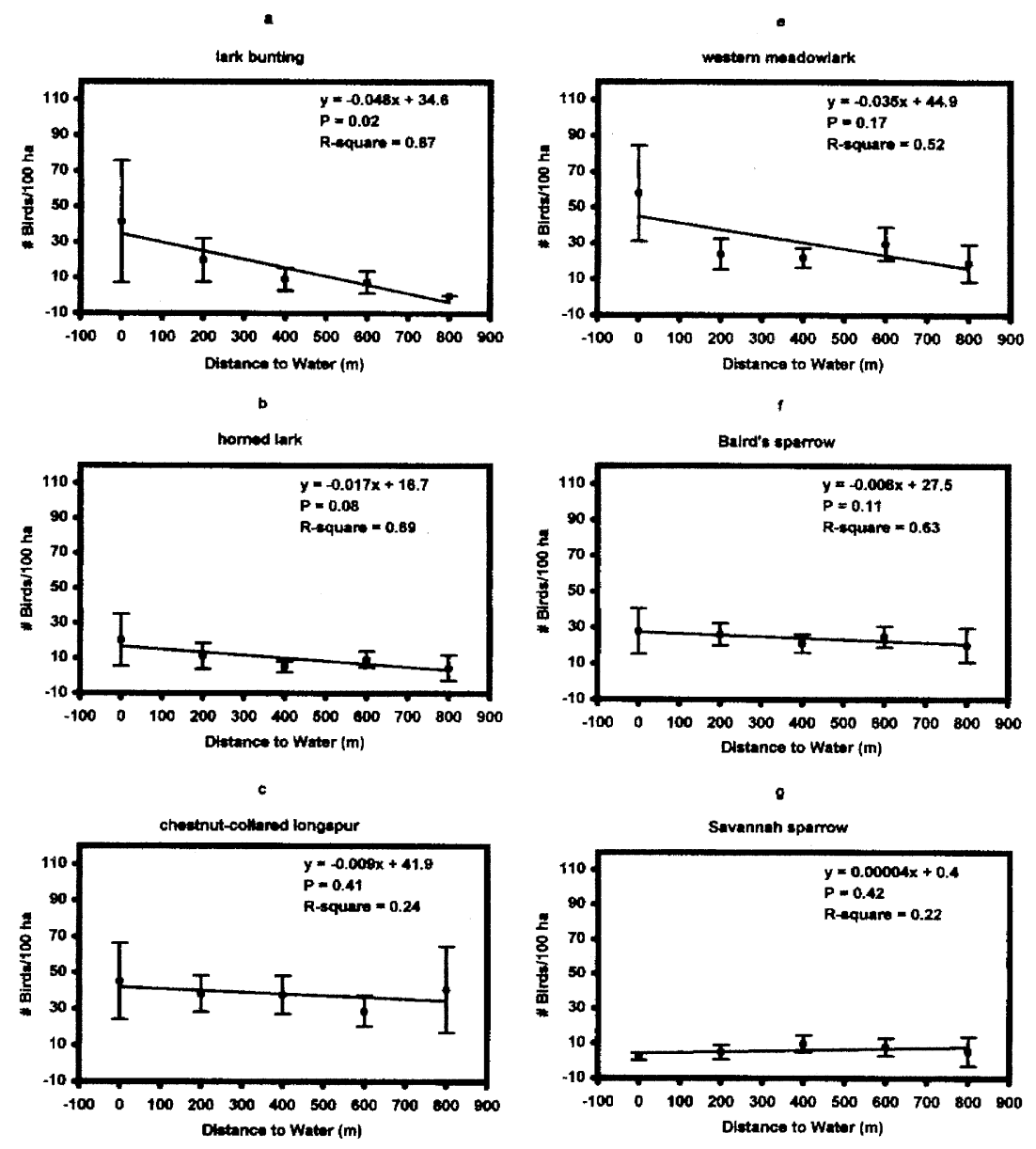

d
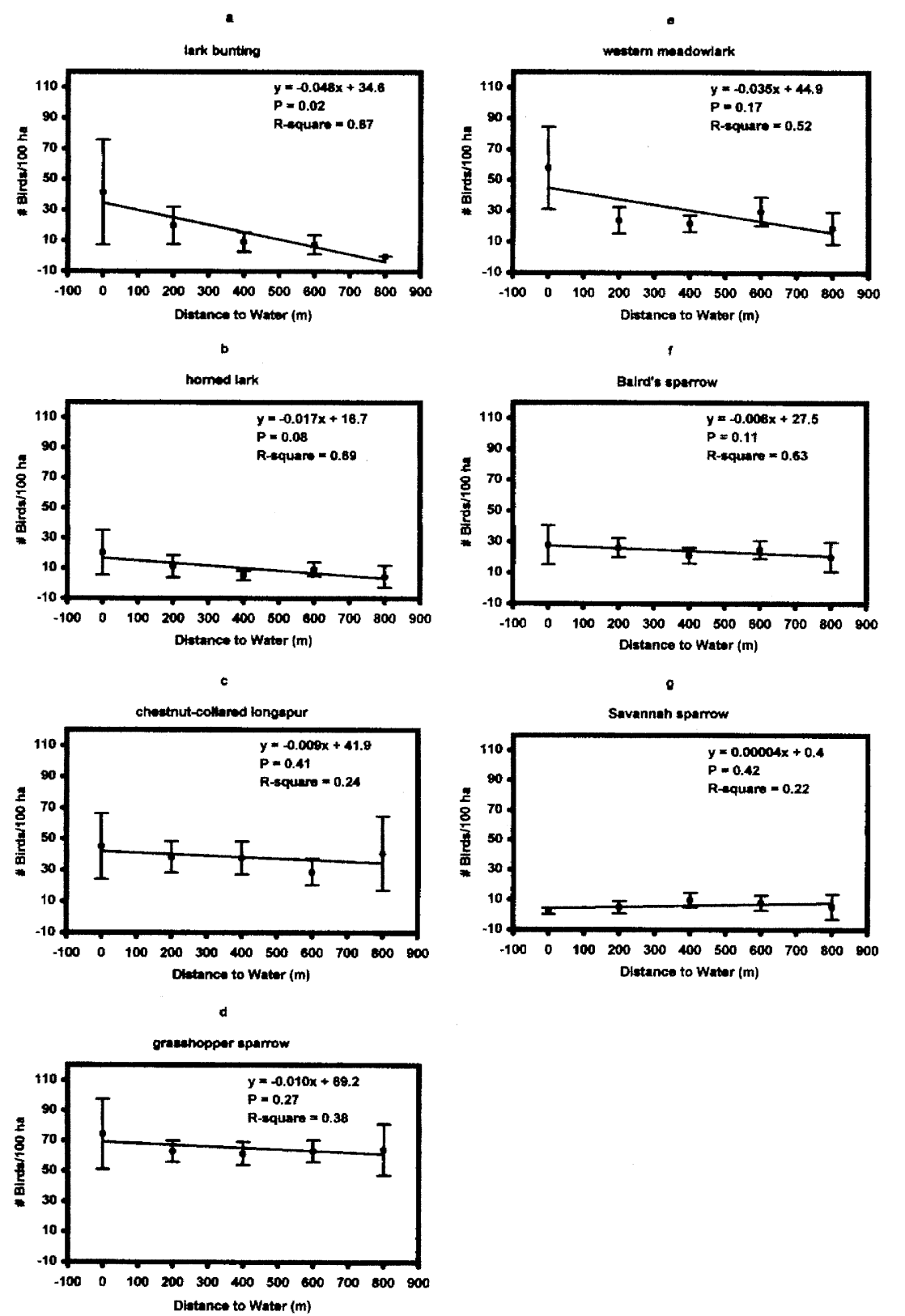

For birds, there was a significant effect of distance on lark buntings (Fig. 2a). There was a decreasing trend, with this species showing higher densities closer to the water developments. The trend was similar, but weaker for horned larks (Fig. $2 b$ ). For all other species, there were no significant trends and confidence interval overlap was substantial (Fig. 2c-g).

Fig. 2. Bird densities (and $95 \%$ confidence intervals) as a function of distance from cattle water developments. Figures a-c depict species typically associated with low vegetative cover; Figures $d$ and e depict species typically associated with moderate vegetative cover; Figures $f$ and $g$ depict species typically associated with high vegetative cover (Kantrud and Kologiski 1983). Data were collected at the Little Missouri National Grassland in 1999 and 2000 . 
For the vegetative and cowpie cover measures, there were significant associations with distance to water in all cases. Robel measure (Fig. 3a) and litter depth (Fig. 3b) increased by 50 and $112 \%$ with distance from water, respectively, and cowpie cover (Fig. 3c) decreased by $51 \%$ with distance from water. CVRobel (Fig. $3 \mathrm{~d}$ ) decreased by $24 \%$ with distance from water indicating within-point variability in vegetative height-density was greater closer to the water developments.

Similar to the avian density data, vegetative variability among sites was substantial resulting in confidence interval overlap between distances in most cases (Fig. 3 ). A preliminary analysis of this vegetative variability was done using principal components analysis (Unpublished data, Fontaine et al.), and the results of this analysis indicated the site variability was not a result of outliers.

\section{Discussion and Conclusions}

Of the species studied, Peterjohn and Sauer (1999) documented declines in all of these species except chestnut-collared longspurs and lark buntings, and Igl and Johnson (1997) documented declines in chestnut-collared longspurs, Savannah sparrows, and western meadowlarks. Therefore, documenting management effects on these species was of particular conservation interest. Of these species, lark buntings showed a density decrease with increasing distance from water developments. The trend for horned larks was similar, although weaker. Lark buntings were not observed at $800 \mathrm{~m}$ points, which may be partially due to the low number of these points on the landscape, but may also be related to the higher vegetative structure. Both species are associated with low vegetative cover in northern mixedgrass prairie, i.e. heavier grazing (Kantrud and Kologiski 1983). Our results support this relationship. However, the other lowcover associate, chestnut-collared longspurs, did not show any trends with distance to water suggesting there is variability in the response of low-cover associates with distance to water developments. The species typically associated with moderate and high vegetative structure (Fig. 2d-g) did not show any trends with distance from water.

The limited literature on this topic suggests that grazing gradients may be diffi-
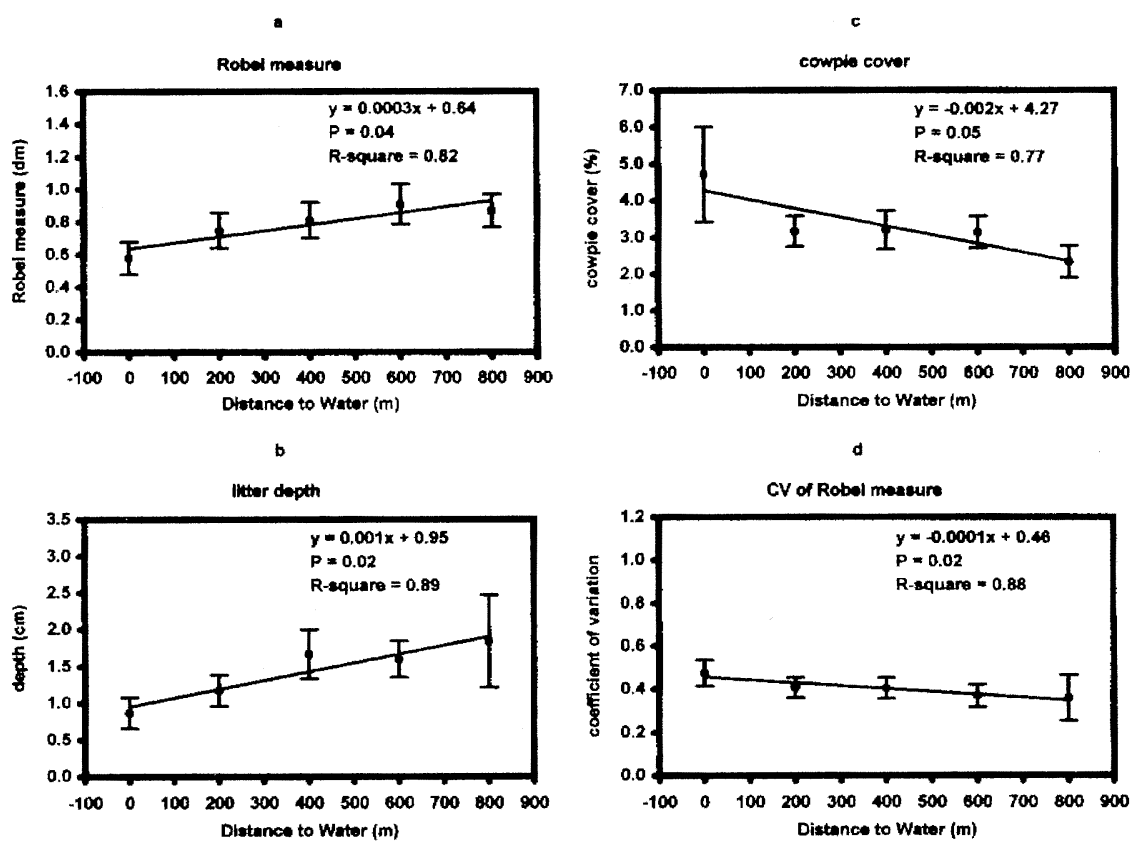

Fig. 3. Means and $95 \%$ confidence intervals of measures of vegetation and cattle use as a function of distance from water developments. Data were collected at the Little Missouri National Grassland in 1999 and 2000.

cult to detect in arid landscapes when water sources are this closely spaced. Roath and Krueger (1982) found vegetative utilization neared zero at $1,900 \mathrm{~m}$ from water on an Oregon rangeland. In mixed-grass prairie/parkland in Alberta, Irving et al. (1995) found vegetative utilization dropped to $50 \%$ at $3,200 \mathrm{~m}$ from water. Although we observed trends in vegetative structure within $800 \mathrm{~m}$ that indicated cattle use was higher closer to water, these trends may have been stronger had we been able to sample at greater distances. Likewise, gradients in densities for chestnut-collared longspurs and the 4 species associated with moderate and high vegetative structure may have been more apparent at greater distances from water.

Our ability to determine the effects of adding water developments on local bird densities would also be strengthened by experiments that measure densities before and after water developments are installed or removed. Alternatively, when range management practices are to be changed, i.e. increase the number of water developments, this change should be treated as a quasi-experiment in which some areas are not modified to serve as controls.

\section{Literature Cited}

Buckland, S.T., D.R. Anderson, K.P. Burnham, and J.L. Laake. 1993. Distance sampling: Estimating abundance of biological populations. Chapman \& Hall, London.

Hansen, P.L., G.R. Hoffman, and A.J. Bjugstad. 1984. The vegetation of Theodore Roosevelt National Park, North Dakota: a habitat type classification. USDA For. Serv. General Tech. Rep. RM-113. Washington, D.C.

Hart, R.H., J. Bissio, M.J. Samuel, and J.W. Waggoner, Jr. 1993. Grazing systems, pasture size, and cattle grazing behaviour, distribution and gains. J. Range Manage. 4:681-687.

Hartnett, D.C., A.A. Steuter, and K.R. Hickman. 1997. Comparative ecology of native and introduced ungulates, p. 72-101. In: F.L. Knopf and F.B. Samson (eds.) Ecological Studies, Volume 125: Ecology and Conservation of Great Plains Vertebrates. Springer, New York, N.Y.

Igl, L.D. and D.H. Johnson. 1997. Changes in breeding bird populations in North Dakota: 1967 to 1992-93. Auk 114:74-92.

Irving, B.D., P.L. Rutledge, A.W. Bailey, M.A. Naeth, and D.S. Chanasyk. 1995. Grass utilization and grazing distribution within intensively managed fields in central Alberta. J. Range Manage. 48:358-361.

Kantrud, H.A. and R.L. Kologiski. 1983. Avian associations of the northern Great Plains grasslands. J. Biogeography 10:331-350. 
Knopf, F.L. 1994. Avian assemblages on altered grasslands. Studies Avian Biol. 15:247-257.

Knopf, F.L. 1996. Perspectives on grazing nongame bird habitats, p. 51-58. In: P.R. Krausman (ed.) Rangeland Wildlife. Society for Range Manage., Denver, Colo.

Lueders, A.S. 2002. Influences of vegetative structure on avian populations under grazing regimes in North Dakota mixed-grass prairie. M.S. Thesis, Colorado State Univ. Fort Collins, Colo.

National Climatic Data Center. 2000. Climatography of the United States, No. 81. North Dakota. National Climatic Data Center/NESDIS/NOAA, Asheville, N.C.
Peterjohn, B.G. and J.R. Sauer. 1999. Population status of North American grassland birds from the North American Breeding Bird Survey, 1966-1996. Studies Avian Biol. 19:27-44.

Roath, L.R. and W.C. Krueger. 1982. Cattle grazing and behavior on a forested range. $\mathrm{J}$. Range Manage. 35:332-338.

Robel, R.J., J.N. Briggs, A.D. Dayton, and L.C. Hulbert. 1970. Relationships between visual obstruction measurements and weight of grassland vegetation. J. Range Manage. 23:295-297.

Samson, F. and F. Knopf. 1994. Prairie conservation in North America. Bioscience $44: 418-421$

SAS Institute. 1990. SAS/STAT user's guide, Version $6.4^{\text {th }}$ ed. SAS Institute, Inc., Cary, N.C.
Thomas, L., J.L. Laake, J.F. Detty, S.T. Buckland, D.L. Borchers, D.R. Anderson, K.P. Burnham, S. Strindberg, S.L. Hedley, M.L. Burt, F. Marques, J.H. Pollard, and R.M. Fewster. 1998. Distance 3.5. Res. Unit for Wildl. Population Assessment, St. Andrews, Scotland.

USDA-USFS. 2001. Land and resource management plan for the Dakota Prairie Grasslands, Northern Region. USDA-USFS, Chadron, Neb.

Walker, J.W. 1995. Viewpoint: Grazing management and research now and in the next millennium. J. Range Manage. 48:350-357.

Weaver, J.E. and F.W. Albertson. 1956. Grasslands of the Great Plains. Johnsen, Bock, and Webb, Lincoln, Neb.

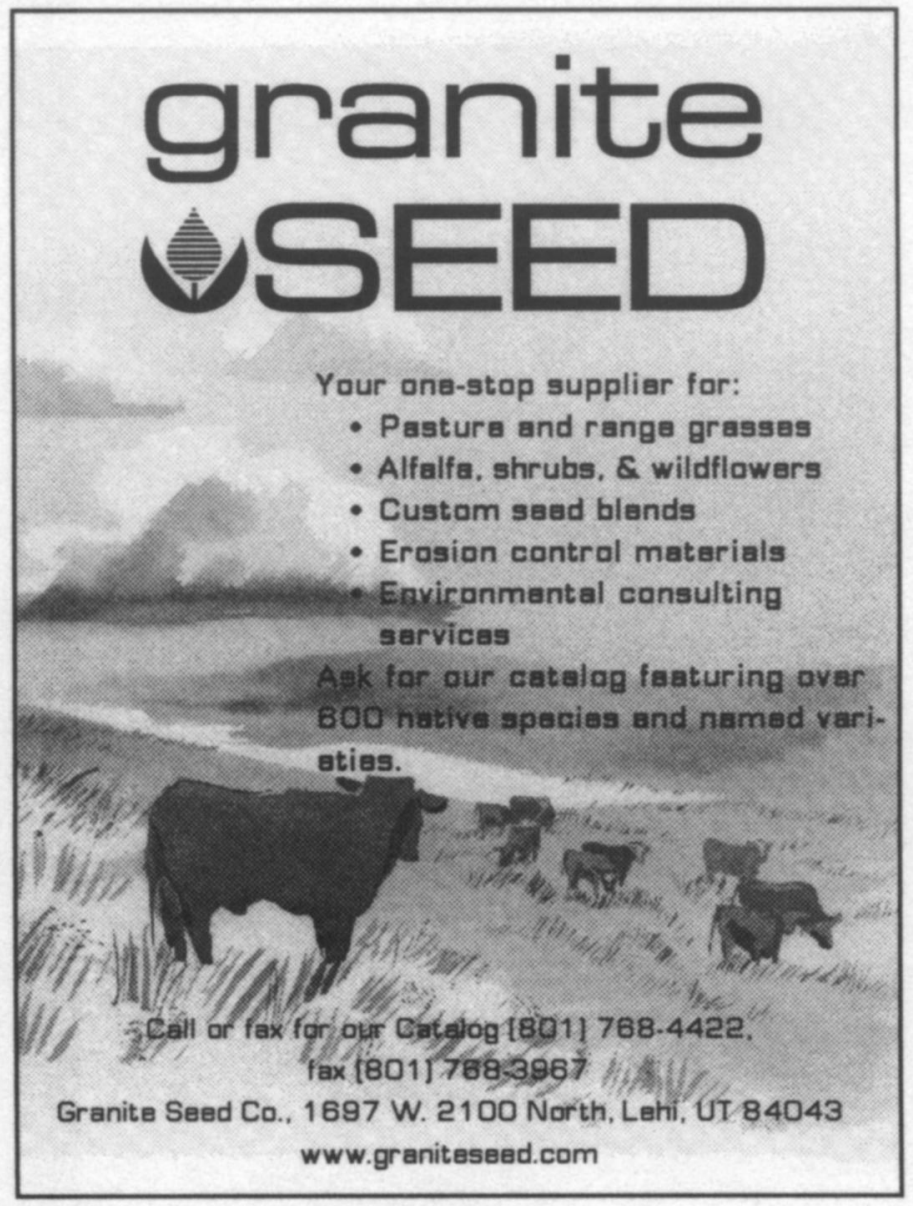

